\title{
الاستعارة سمة أسلوبية - ديوان طين الأبدية أنموذجا
}

\section{The metaphor is a stylistic feature - the eternal clay poem as a} model

slel

\section{د.أيمن خميس عبد اللطيف أبومصسطفر}

Doi: $10.12816 / \mathrm{mdad} .2020 .122949$

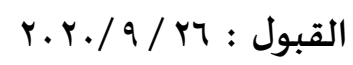

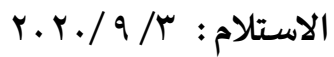

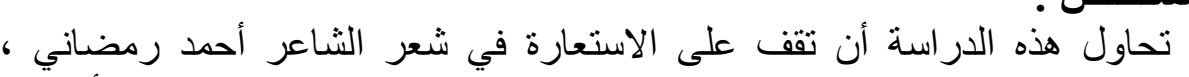

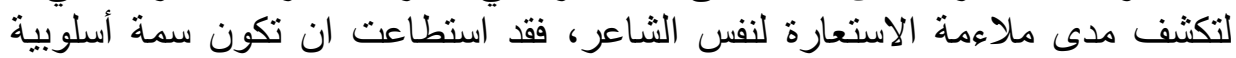

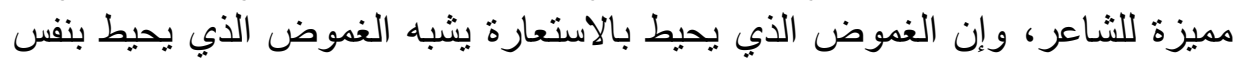

\section{Abstract:}

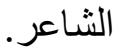

This study attempts to find a metaphor in the poetry of the poet Ahmed Ramadani, to reveal the appropriateness of the metaphor for the same poet, it has been able to be a characteristic stylistic feature of the poet, and the ambiguity surrounding the metaphor is similar to the mystery surrounding the same poet.

إن الباحث سيقف هنا مع ديوان طين الأبدية للشاعر العر اقي أحمد محمد رمضان'

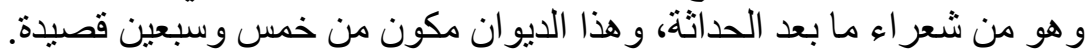

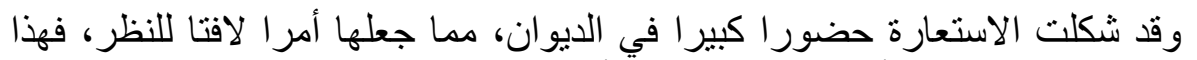

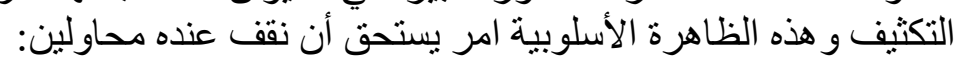

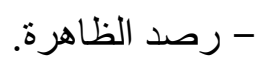

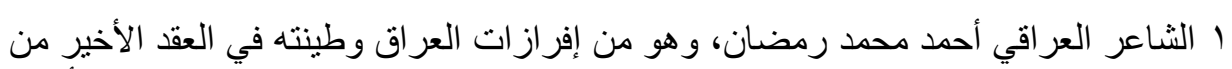

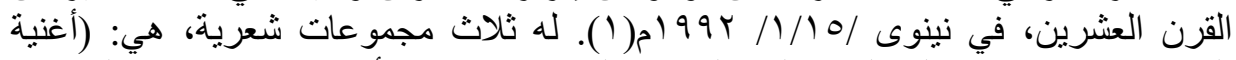

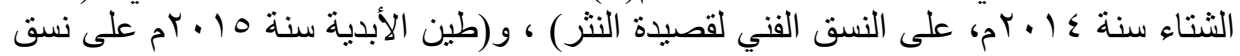

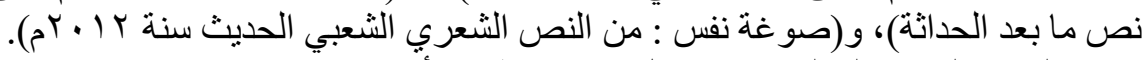

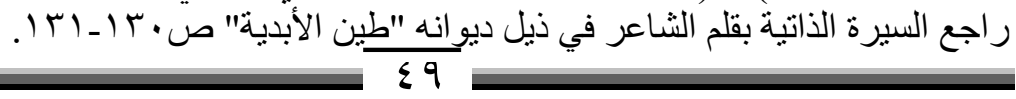




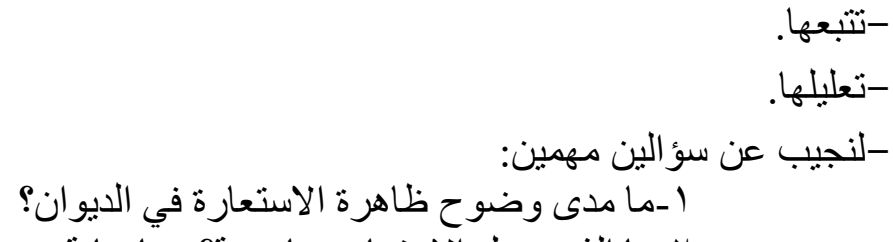

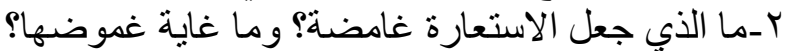

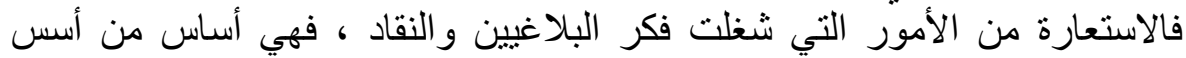

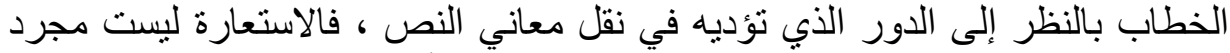

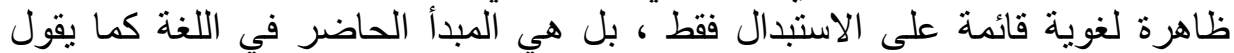

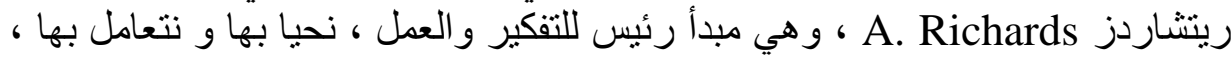

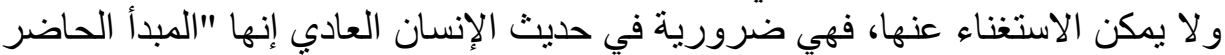

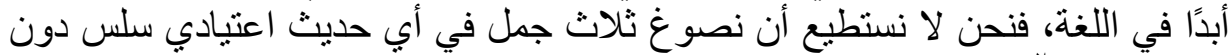

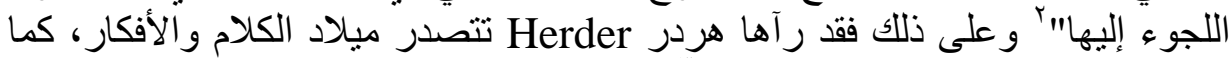

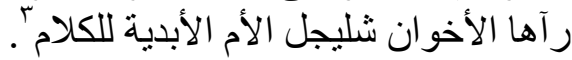

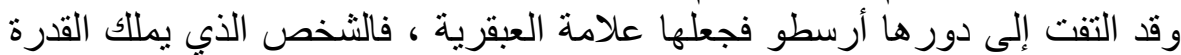

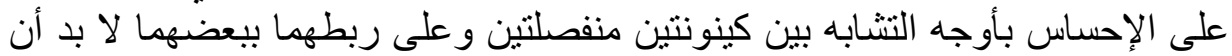

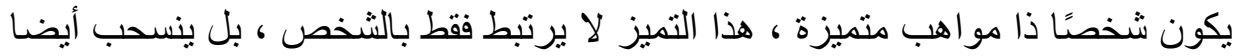

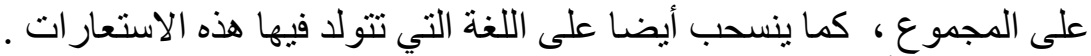

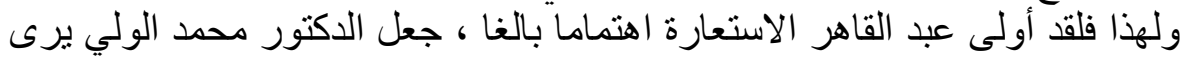
أن الاستعارة قد هيمنت على كل كتاب أسرار البلاغة ، ثنما بالغا، راجعها في كتاب دلائل

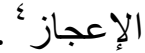
فهي إحساس عميق بالأشياء، بحيث تعكس حالة توحد المبدع بالأشياء، فتكون رؤية

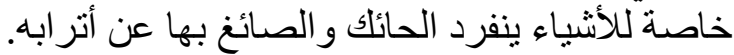

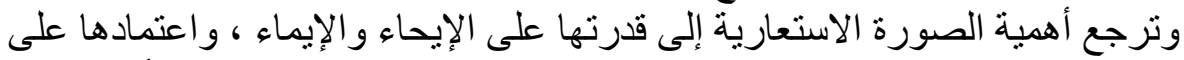

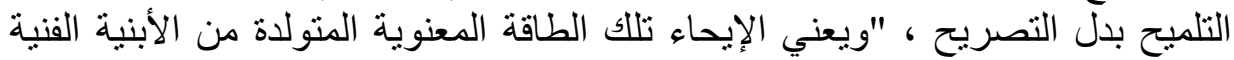

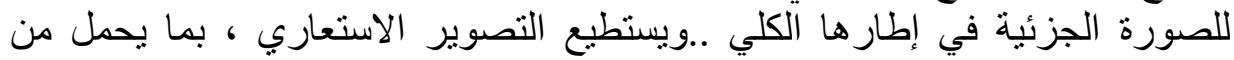

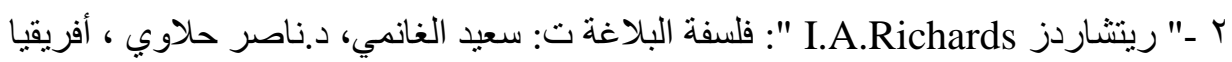

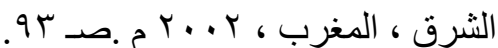

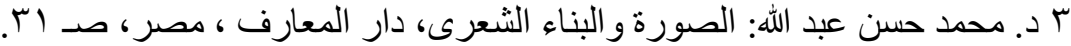

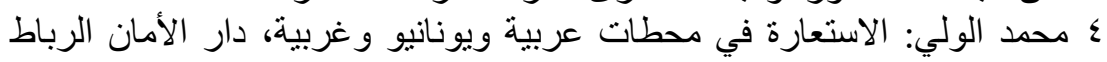




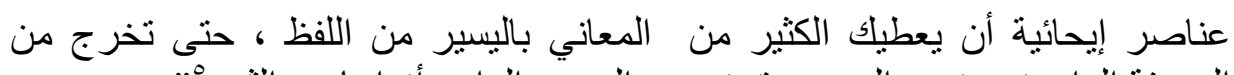

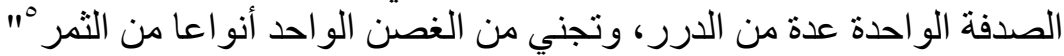

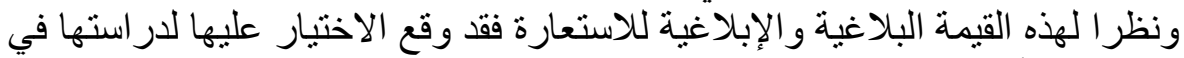

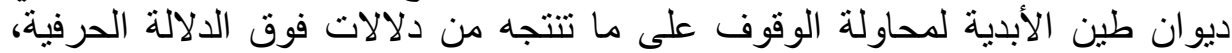

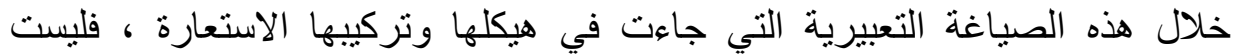

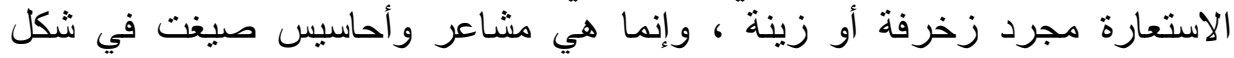
تصويري ، والباحث يحاول في هذه الصفحات قراءة نفرة نفس الثاعر خلال الاستعارة.

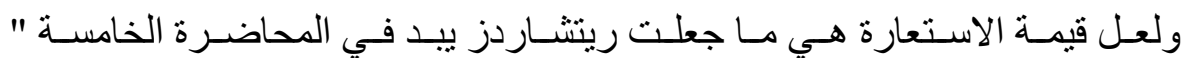

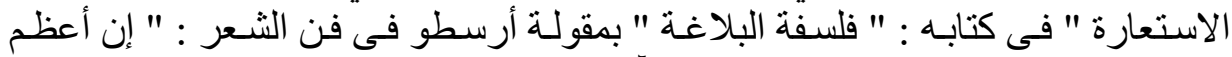

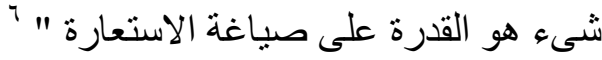

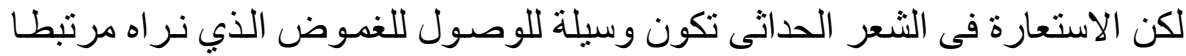

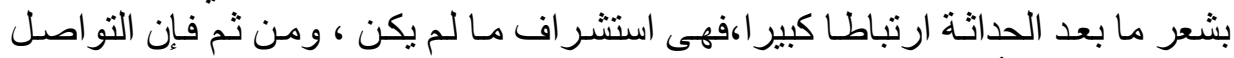

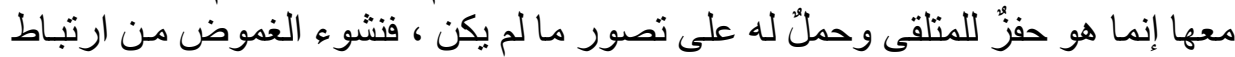

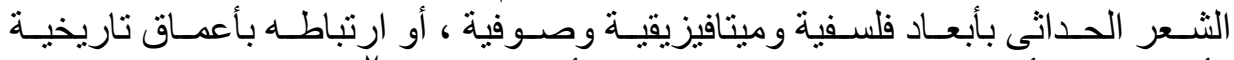

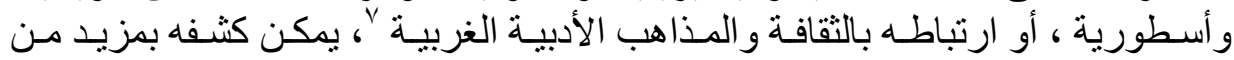

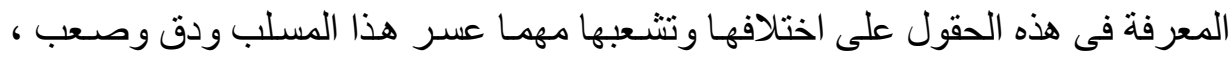

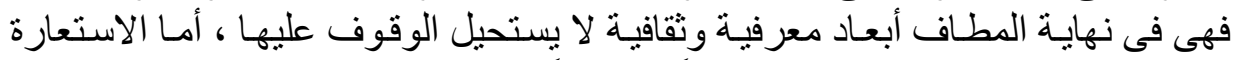

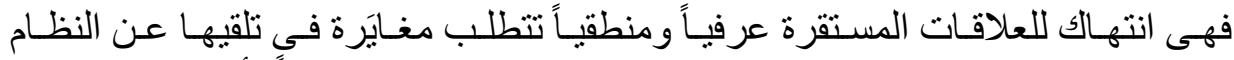

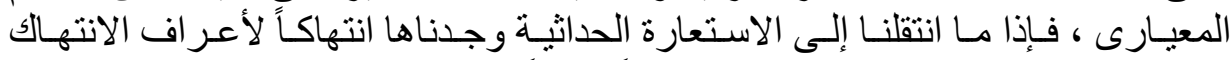
المعهودة التى استقر عليها عقل المتلقى زمناً طويلاً.

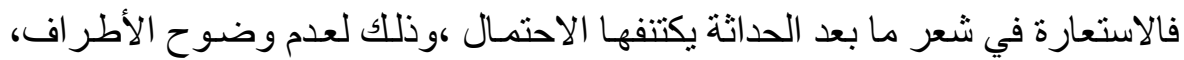

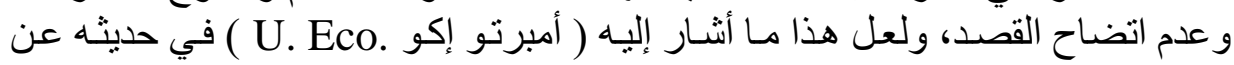

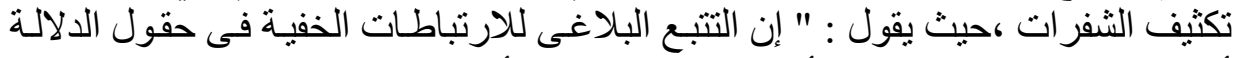

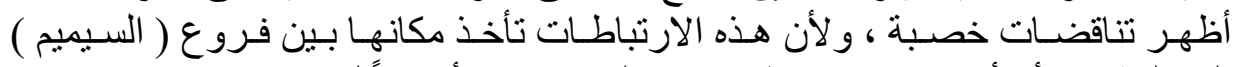

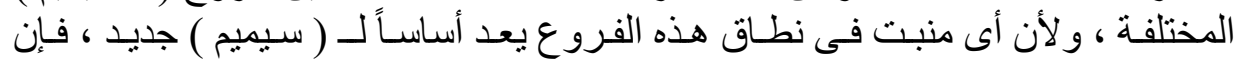

ميوسف أبو العدوس: الاستعارة في النقا الأدبي الحديث،الأبعاد المعرفية والجمالية،

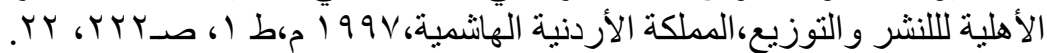

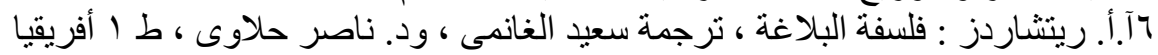

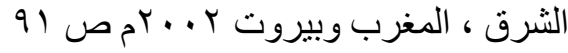
V د د ـ يوسف نوفل : استثفاف الثعر ، الثركة المصرية العالمية للنثر، لونجمان ، القاهرة 
الاستبدال البلاغى ـ عن طريق تكوين مزيد من الارتباطات ـ يقوم بتحريك السلسلة

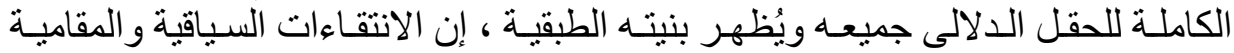

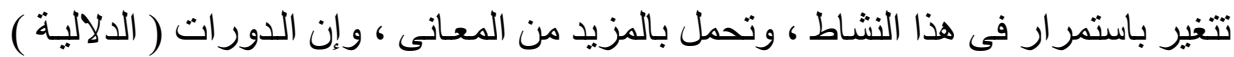

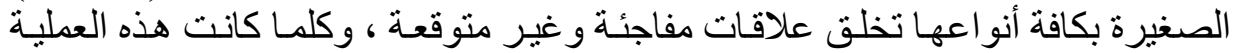

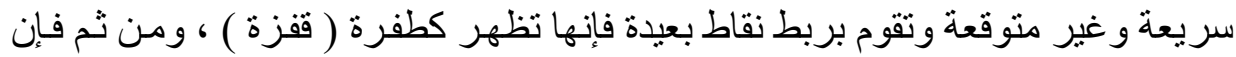

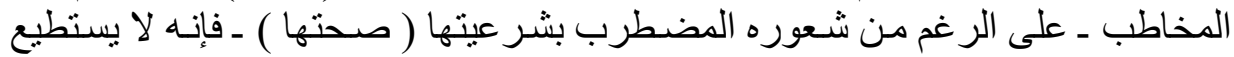

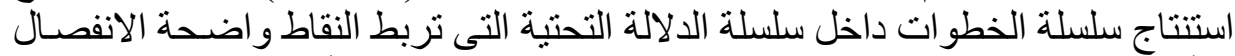

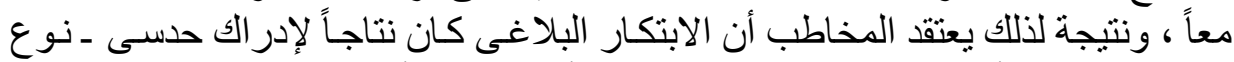

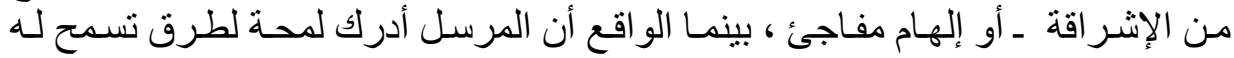

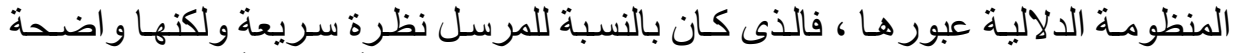

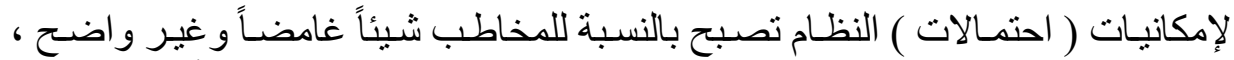

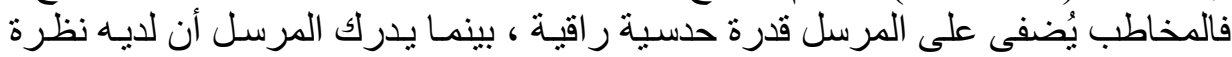

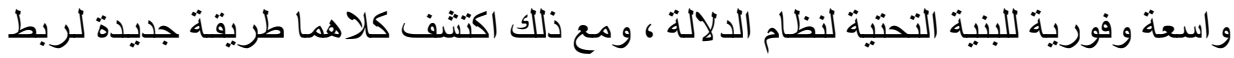

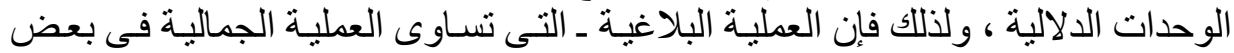

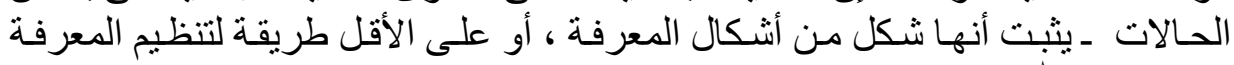

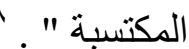

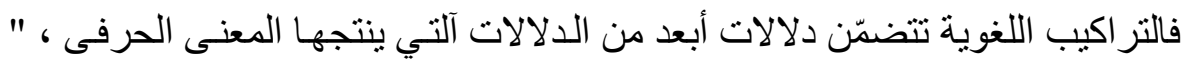

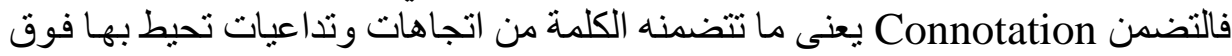

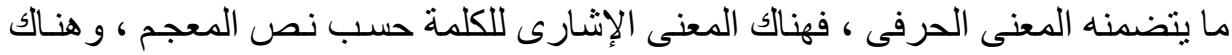

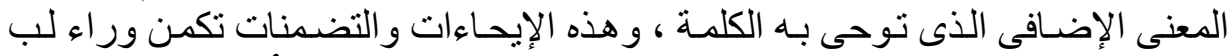

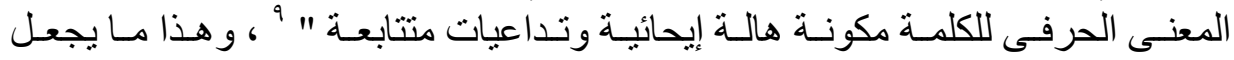

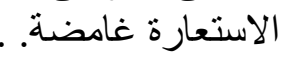

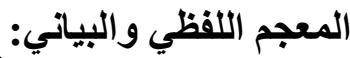

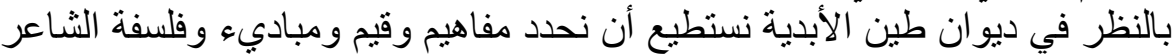

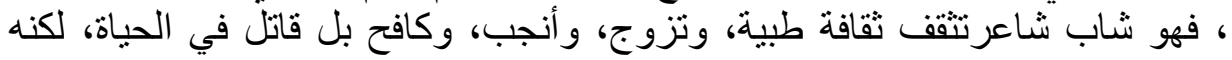

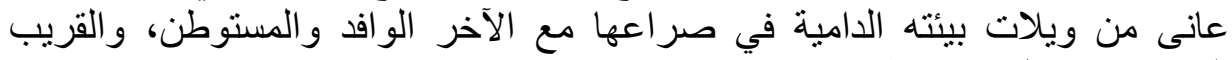
المتربص! يقول من مقطو عتهان(حياتي):

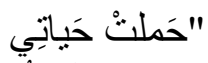

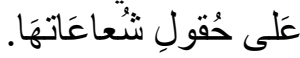

Eco, U : A Theory of Semiotics, Indiana University Press, 1976. P.283 ^ 9 د. يوسف نوفل : أصو ات النص الثعرى، مرجع سابق ص 9 هو 
قَتِ

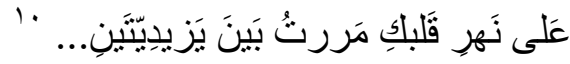

ويقول:

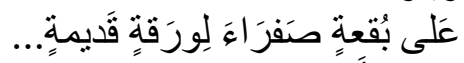
نَثْرِي أَبِي

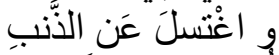

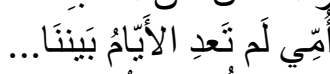

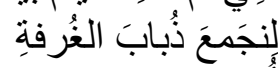

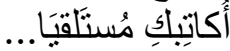

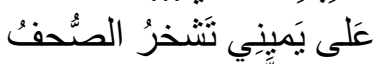

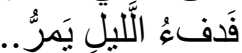

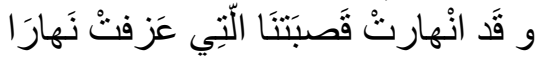

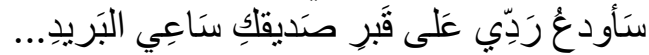

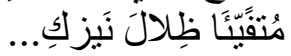

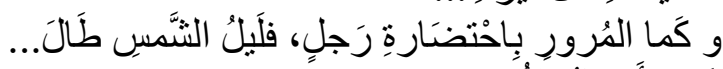

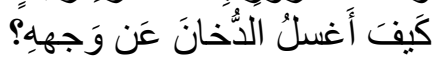

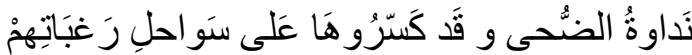

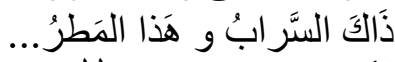

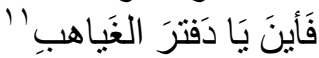

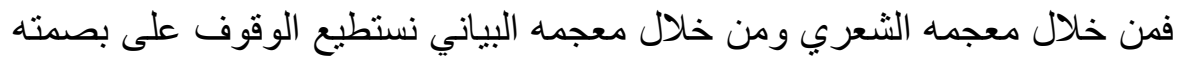

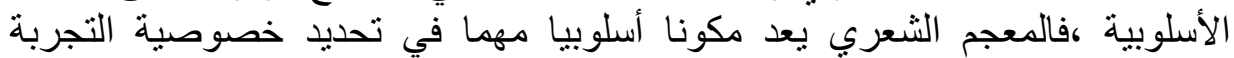

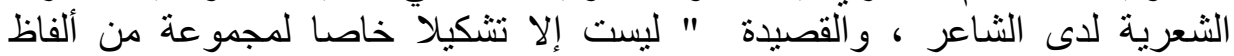

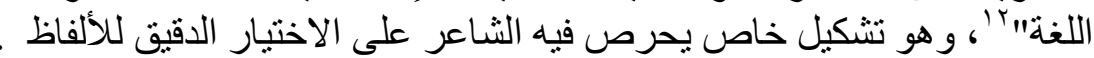

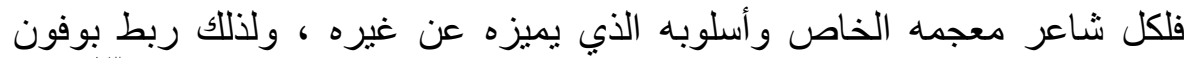
buffon

$$
\begin{aligned}
& \text { • اديوان "طين الأبدية"، صـ7 } 7 .
\end{aligned}
$$

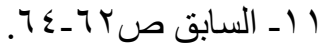

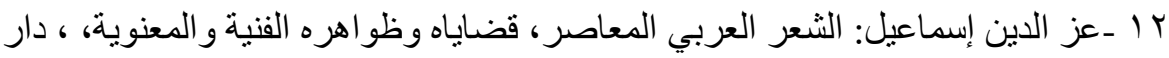

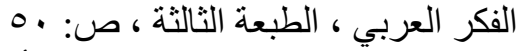
با ـ الهادي الجطلاوي: مدخل إلى الأسلوبية تنظير اوتطبيفا، منشور ات عيون، الدار البيضاء، 
أنتار الجاحظ قديما إلى هذا التصور، معتبرا أنّ لكل شاعر ألفاظا محددة تدور في في إنداع

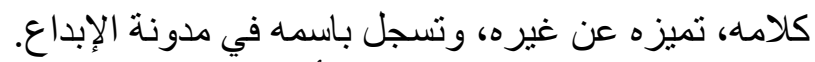

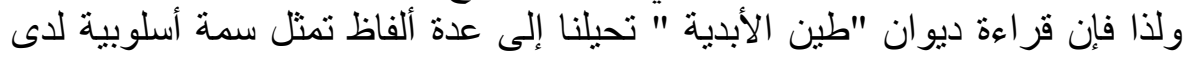

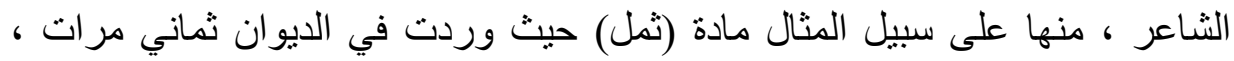

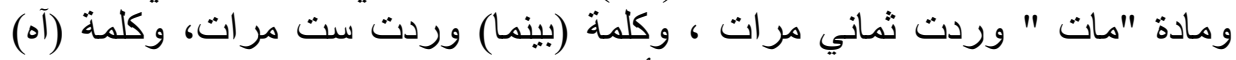

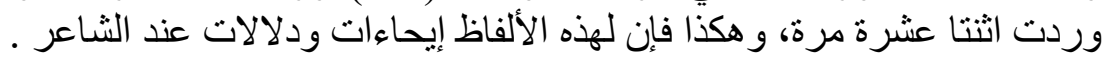

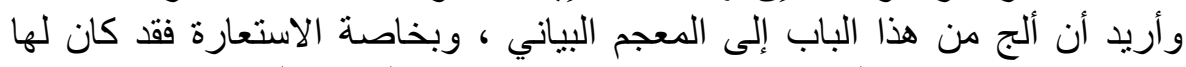

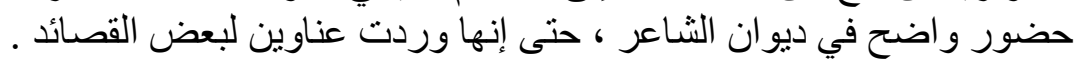
الاستعارة في آلعنوان:

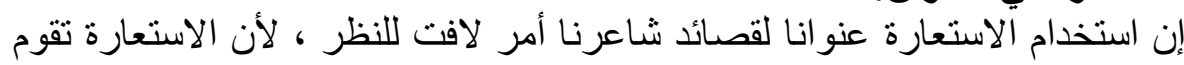

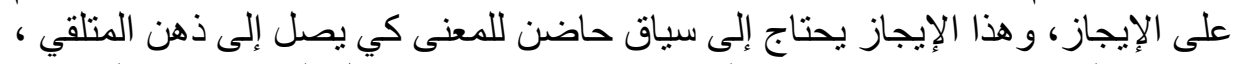

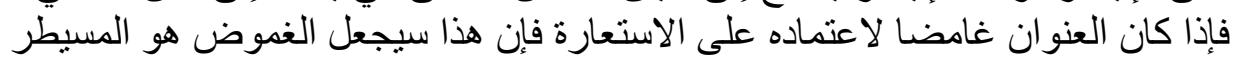
على العمل كله.

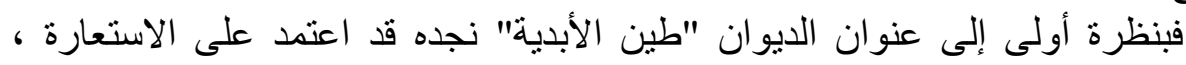

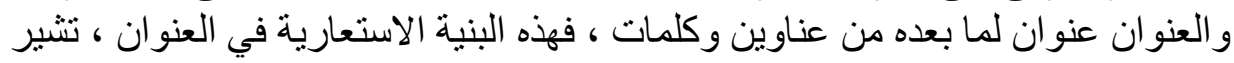

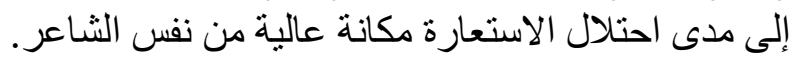

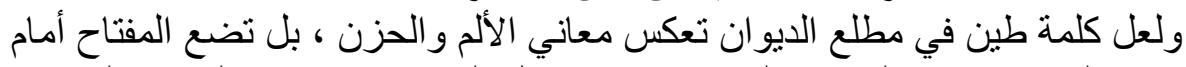

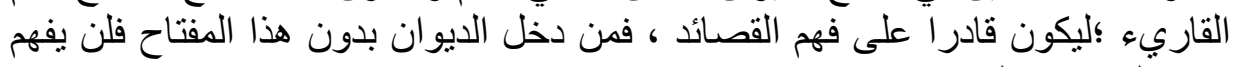

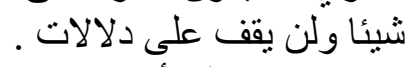
فلاشك أن الاستعارة حاضرة حضورا واضحا في معجم الثاعر البياني ،

$$
\begin{aligned}
& \text { فبتأمل هذه القصيدة : فلان } \\
& \text { قُوسن فُزْ حِ }
\end{aligned}
$$

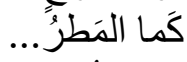

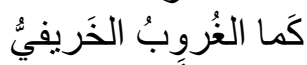

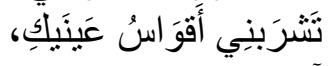

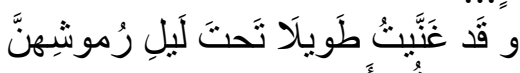

مَعزوفةُُ الأَخادِيدَ.

نجد أن أن الاستعارة تحيط بالقديدة القعارة إحاطة القلادة بالعنق و السوار بالمعصم :

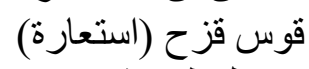

كما المطر (تشبيه)

$$
\text { كما الغروب (تشبيه) }
$$




$$
\text { غنتربني أقو اس (استعارة) }
$$

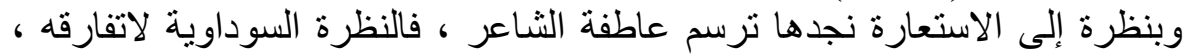

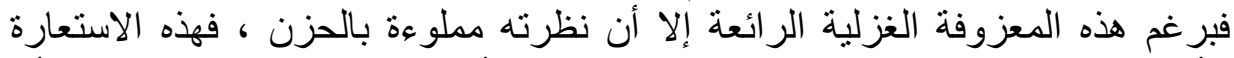

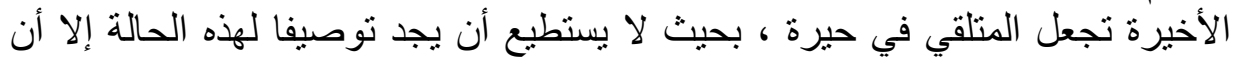

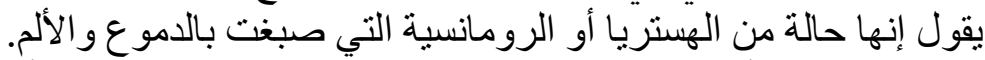

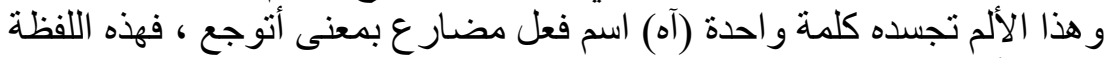

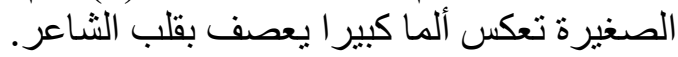

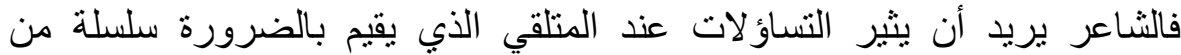

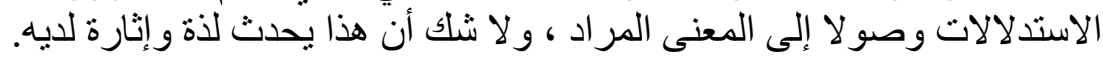

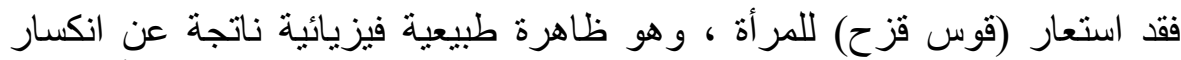

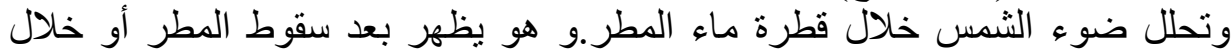

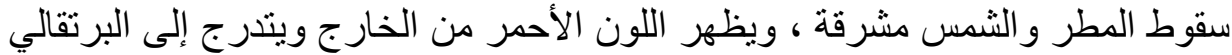

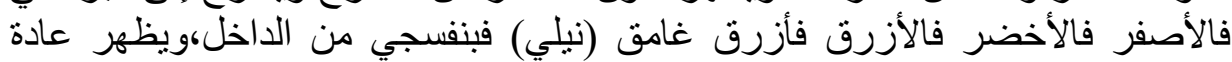

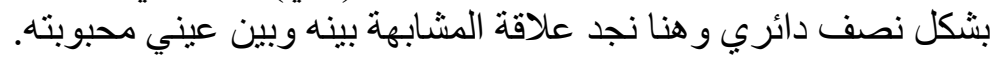

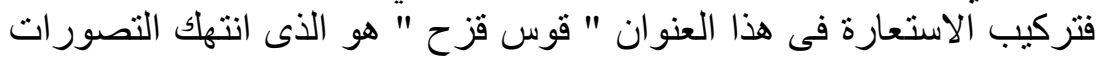

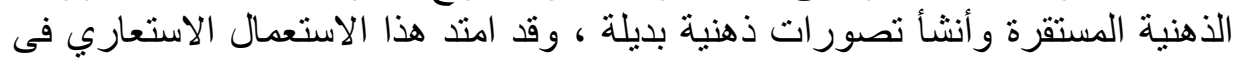

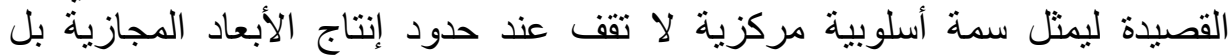

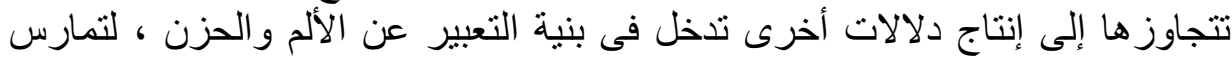

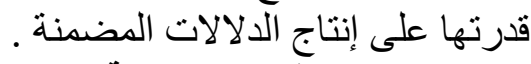

$$
\begin{aligned}
& \text { الاستعارة وغموض النارة الالالة: }
\end{aligned}
$$

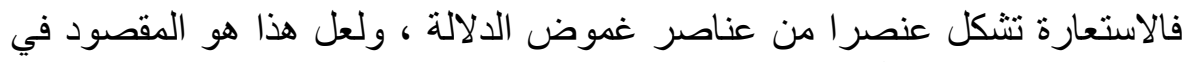

$$
\begin{aligned}
& \text { شعر ما بعد الحداثة ، يقول : شئن } \\
& \text { طُبْولٌ }
\end{aligned}
$$

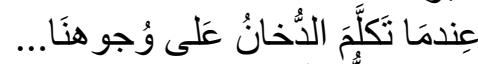

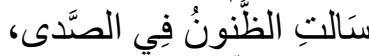

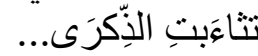

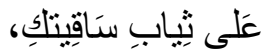

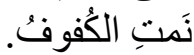

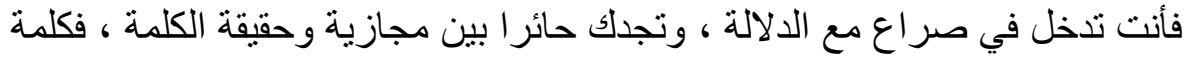
طبول التي جاءت عنو انا للقصيدة كلمة غائمة ولكن دلالة القصيدة تدفعنا نحو توقع دلالة 
ذات أثز محزن ، فالطبول عادة ما تكون قرينة لمداهمة شر ، وقد ذكرها الثاعر

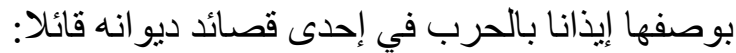

$$
\begin{aligned}
& \text { غُويرَا }
\end{aligned}
$$

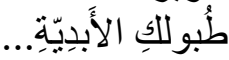

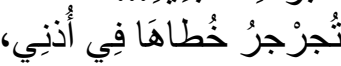

$$
\begin{aligned}
& \text { كَرسُولِ نَسِيَ شَمَائلِّهُ... }
\end{aligned}
$$

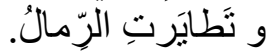

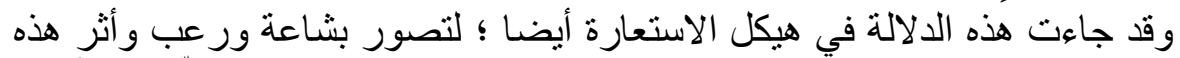

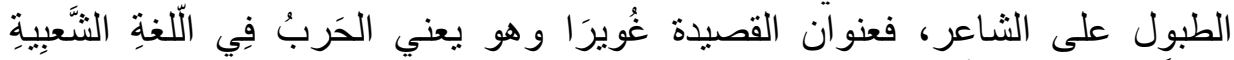

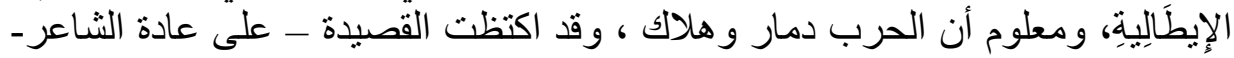

بالاستعار ات فنجد:

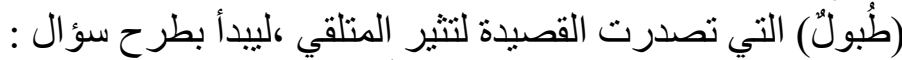

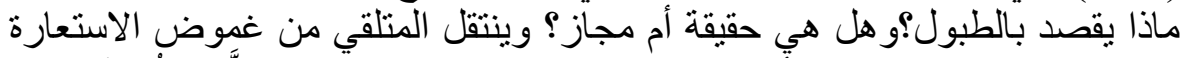

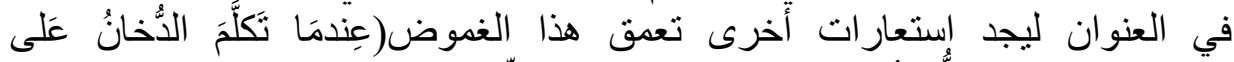

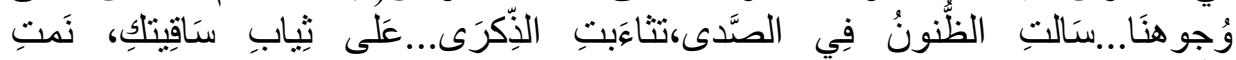
الكُفوفن) فإن خفاء الدلالة جعل كل كلمة من كلمات هذه القصيدة تنتج كثير ا من الدلالات ، فأي

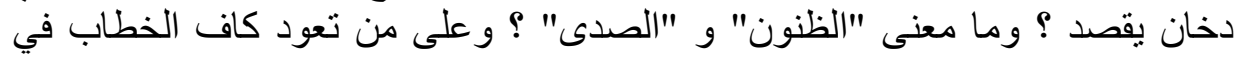

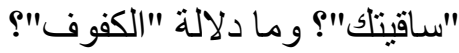

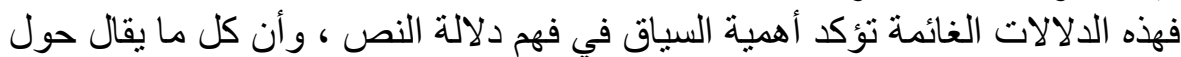

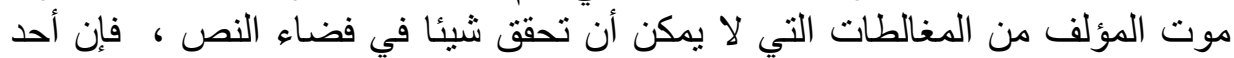

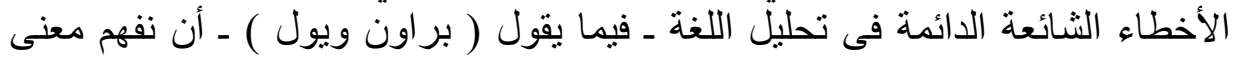

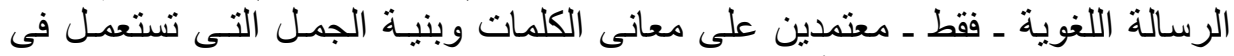

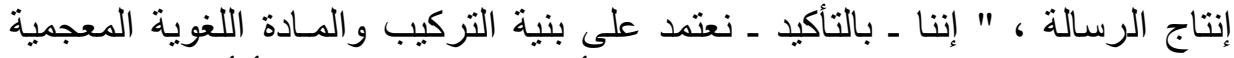

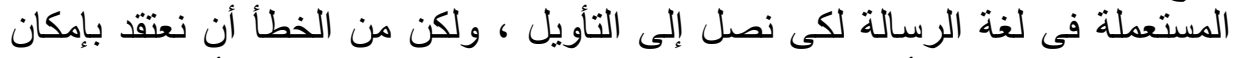

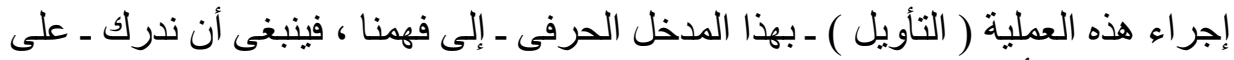

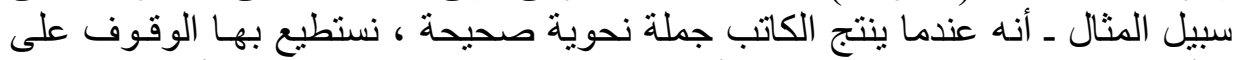

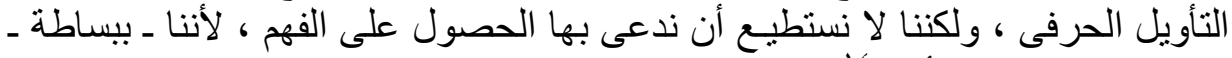

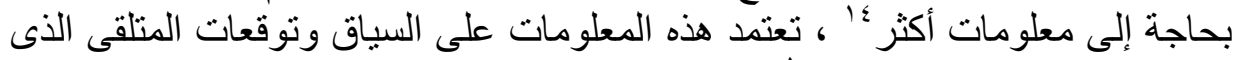

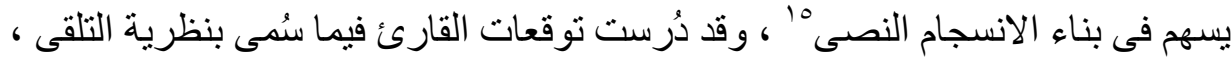

Brown . G. Yule: Discourse Analysis . Cambridge.1983 . P. 223 -'

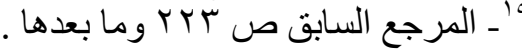




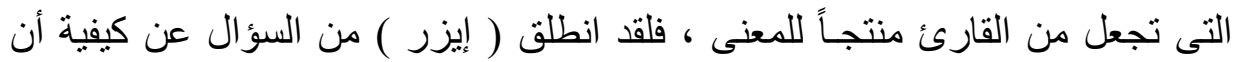

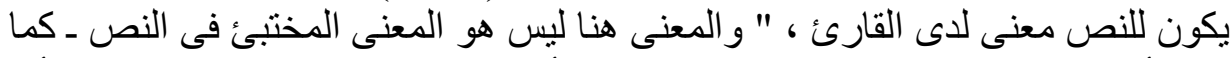

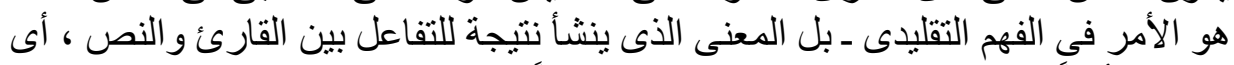

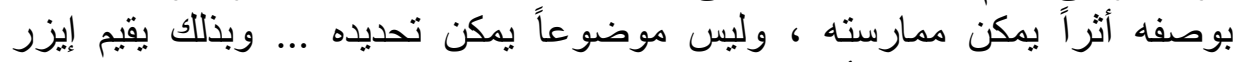

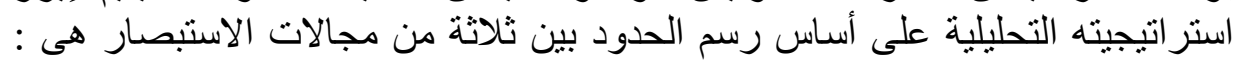

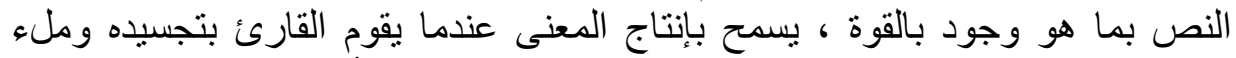

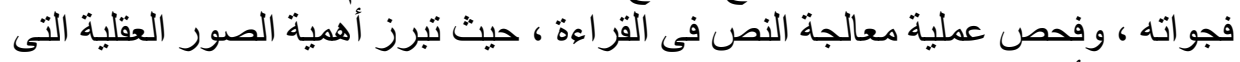

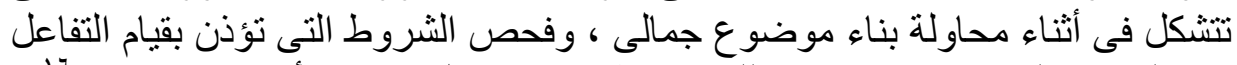

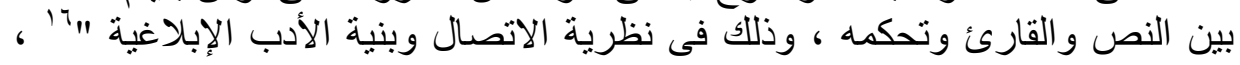

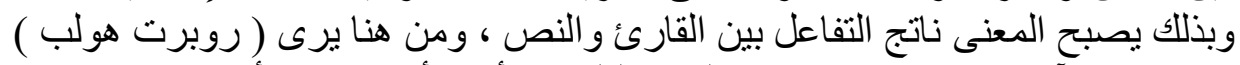

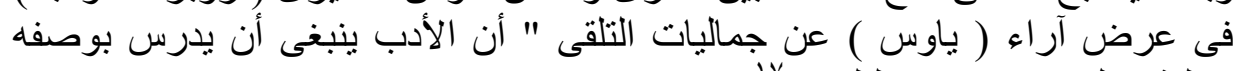

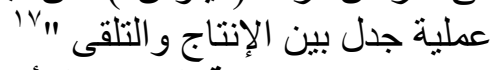

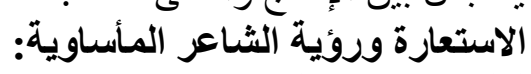

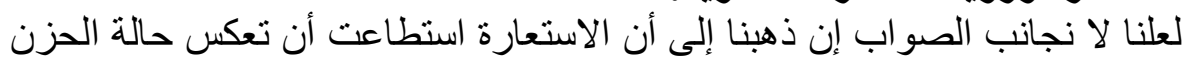

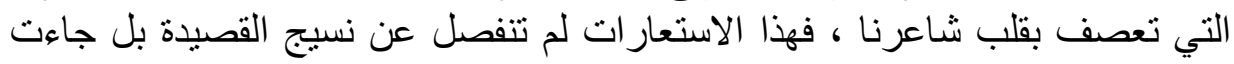
القصيدة في نسيجها ، فحينما تجده يخاطب ، فئب الموت فائيألا:

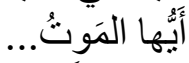

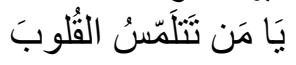

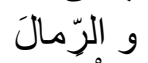

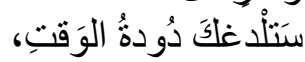
كَما الكَبشُ....

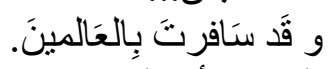

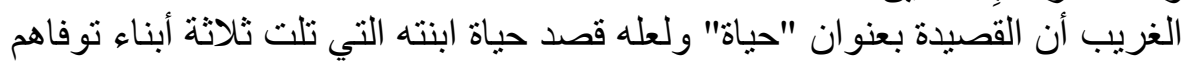

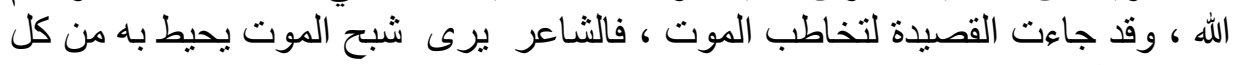

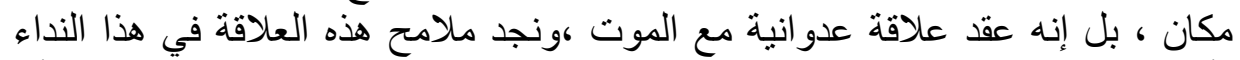

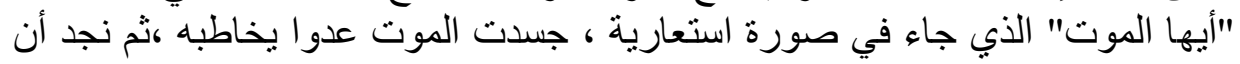

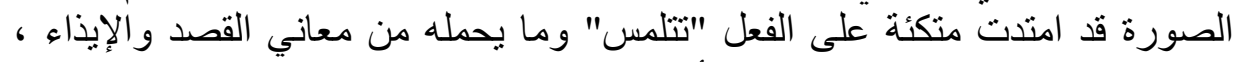
فالموت يقطع عن شاعرنا كل ما يظن أنه سبب للفي للحياة.

"'ا' روبرت هولب : نظرية التلقى ، ترجمة د.عز الدين إسماعيل ، ص 9 ا ل ، مقدمة المترجم . 
ولا يجد إلا أن يمني نفسه بما يشفي غليله ، "ستلاغلك"استعارة "دودة الوقت

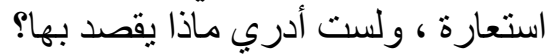

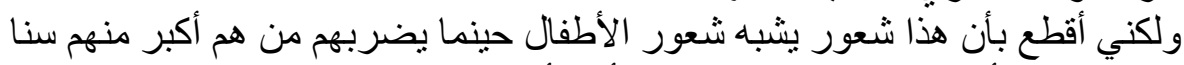

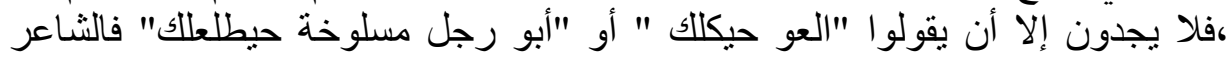

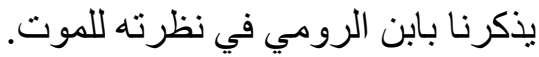

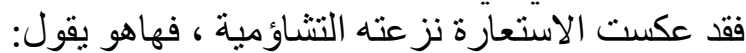

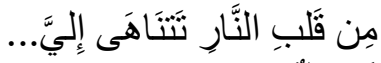

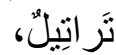

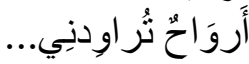

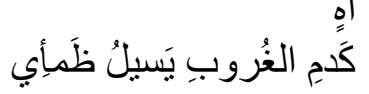
بَاردَا. فالاستعارة شكلت ظنون الثاعر ورسمت ما بداخله من ألم وحزن ، فإن أفكار أفكاره التي

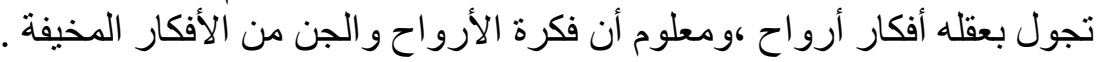

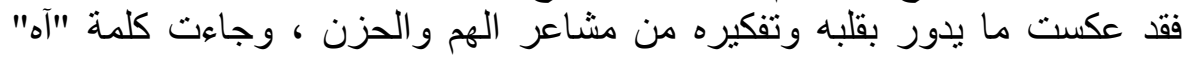
لتجسد ذلك الحزن الدفين. و هي تتكرر كثير ا في معجم الثاعر اللغوي ،فقد جاءت أيضا في قصيدته التي ترسم بالكلمات معاني اليأس والألم الميث حيث يقول:

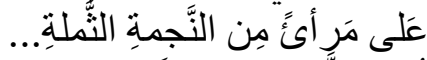

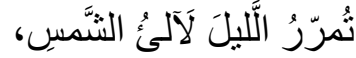

\section{تُعُلِّقُ طَيَفِهَا القَنَاديلُ.}

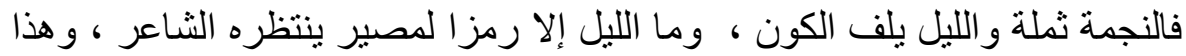

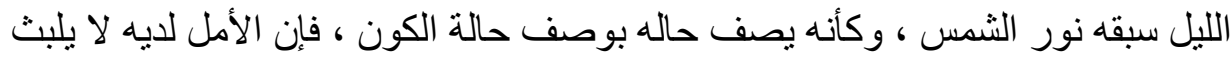
قليلا إلا وقد انقلب ألما. وفِّيُّة قصيدته "ضفة" نجد الاستعارة تعكس التشاؤم الذي يملأ قلب الثاعر، يقول:

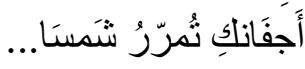
بَيَنمَا عَلى الثَّوَّواطئِ... تَسكنُ لَيلةُ أَبِيَيَّةُ، !. 


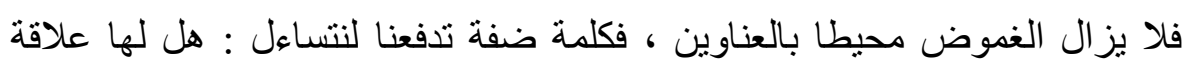

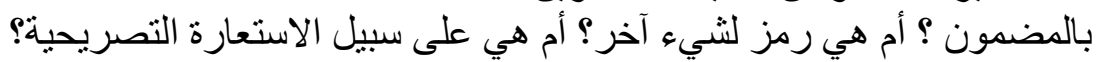

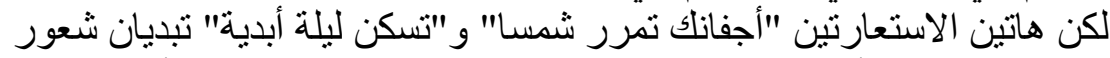

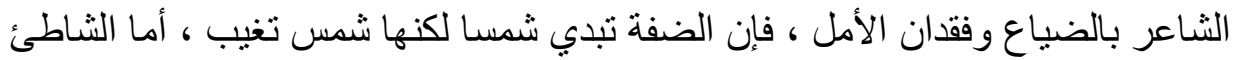

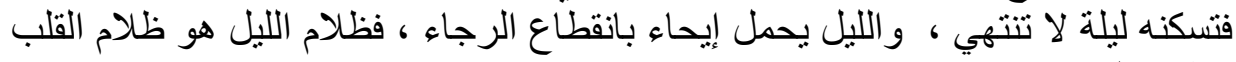

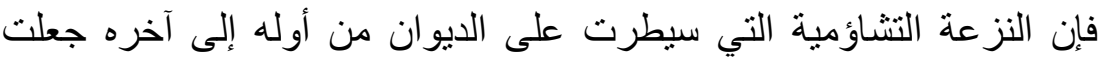

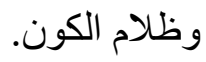

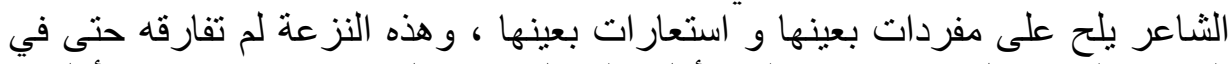

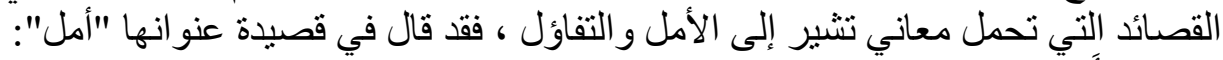

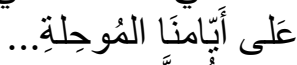

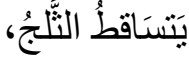

$$
\begin{aligned}
& \text { عِندمَا... }
\end{aligned}
$$

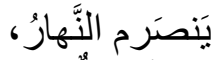

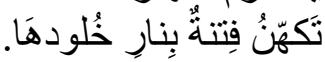

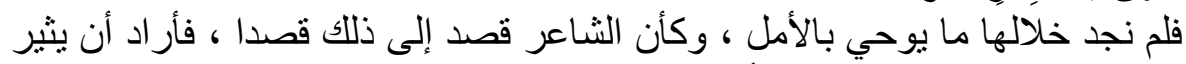

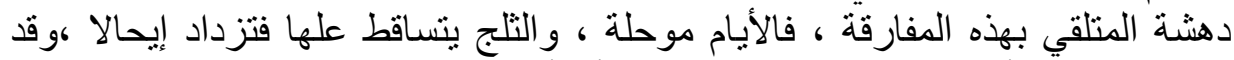

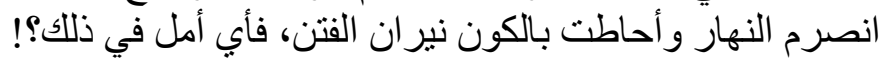

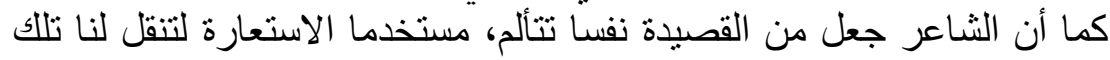

$$
\begin{aligned}
& \text { المعاناة،يقول: } \\
& \text { [قَّصنيُة: }
\end{aligned}
$$

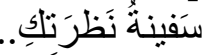

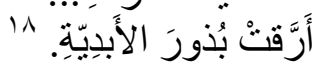

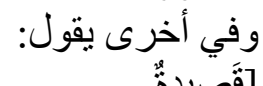

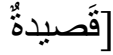

$$
\begin{aligned}
& \text { عُمَيَانَا.... } \\
& \text { خَرَّبُو انَدَاوةَ خَدَّلكِ. } 19
\end{aligned}
$$

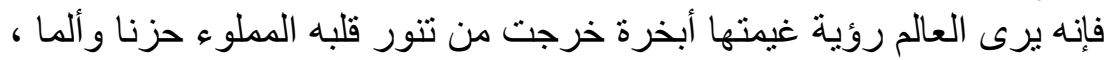

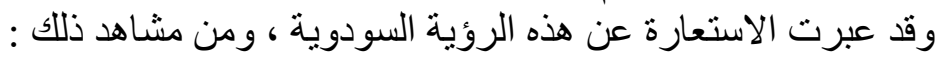

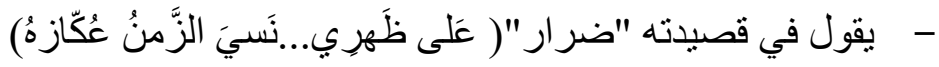

$$
\text { 1 الديو انه "طين الأبدية"، ص } 1 \text { صابة. }
$$

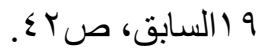


فهذا الزمان الثقيل الذي أنقل ظهر شاعرنا لايريد مفارقته ، فهذه الاستعارة التي

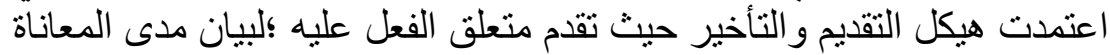
التي يمر بها الثاعر. - ويقول في قصيدة بعنوان "تتاص مع الأبدية" (حَباتِي...يَجرّ هَا يَأسُ طُحلبٍ، و هِي

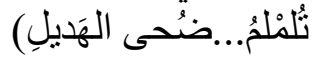
هذه العلاقة بين مقدار يأسه من حياته ومقدار يأس الطحلب من نيل ما يشتنهيه

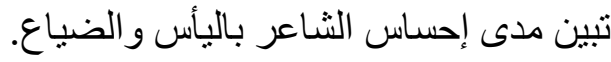

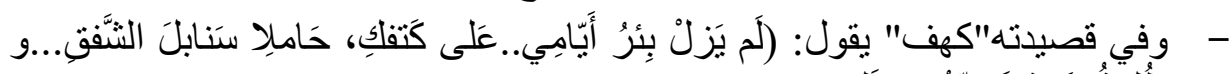

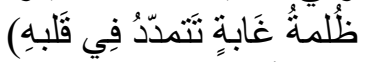

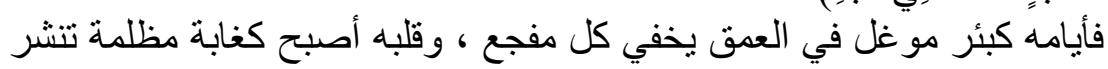

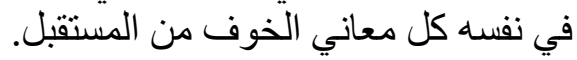

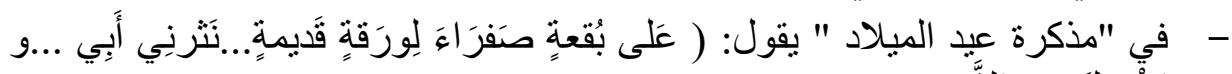

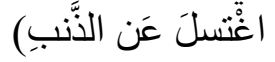

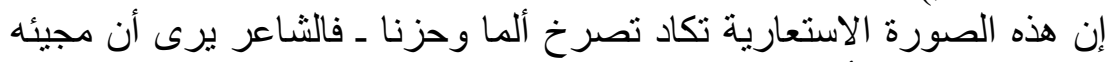

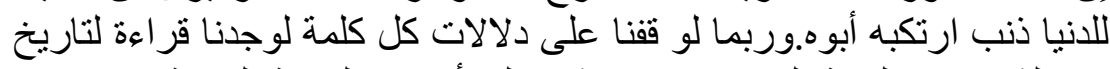

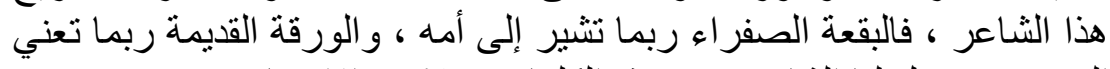

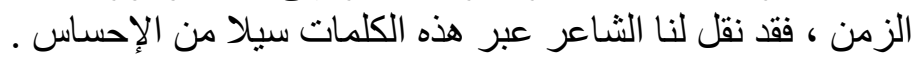

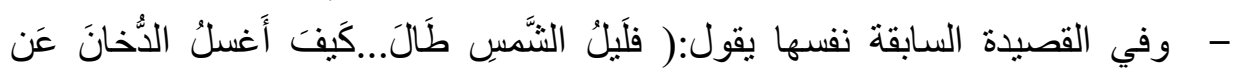
وَجهِهِ

فأي ليل سوى ليل الألم و الحزن واليأس ، وهذا السؤال الذي يعكس المعاناة

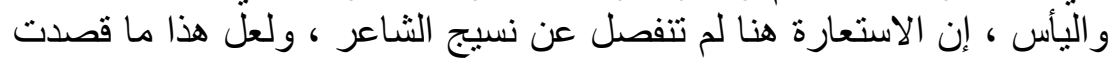
إليه في هذه الدر اسة.

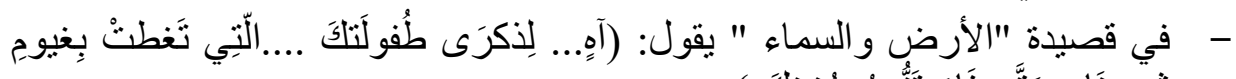

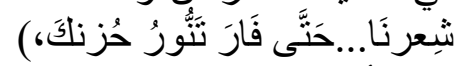

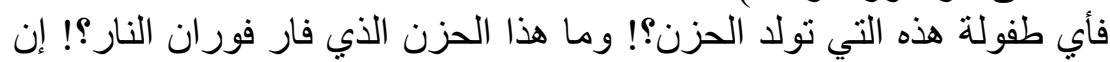

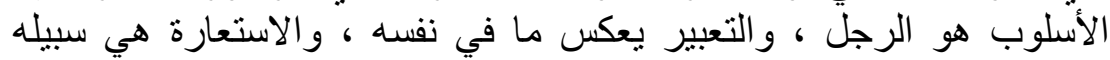

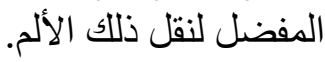

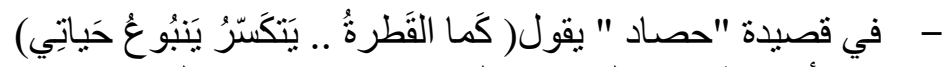

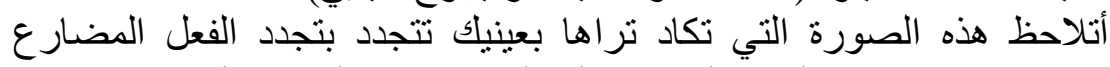

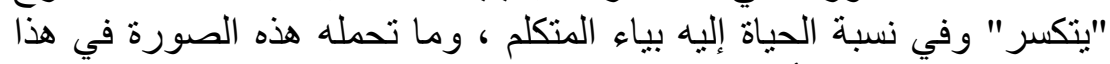
التركيب الإضـافي من ألم يتجدد؟ 


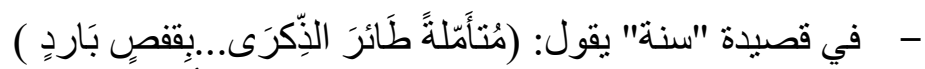

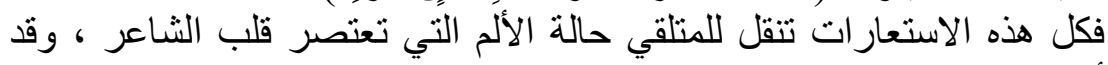

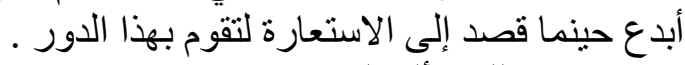

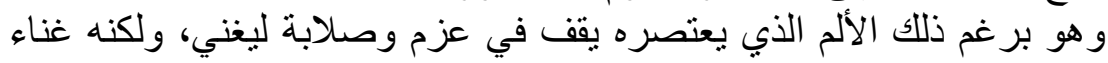
بشبه رقص الطائر وقع في النار ، يقول:

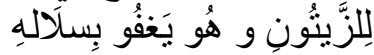

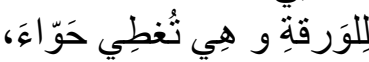

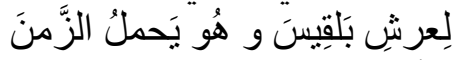

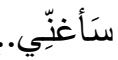

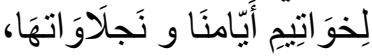

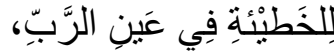
سَأغنِي....

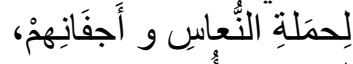

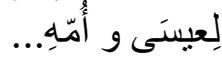

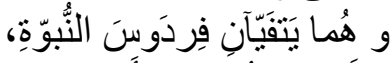

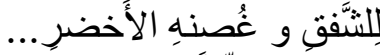

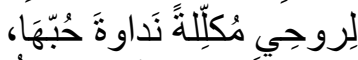

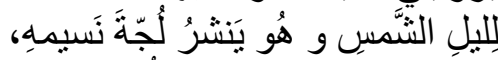

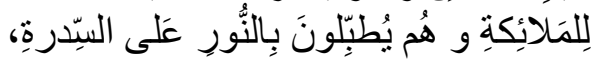

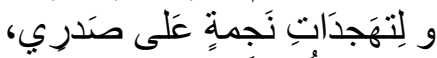

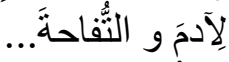

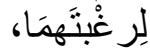

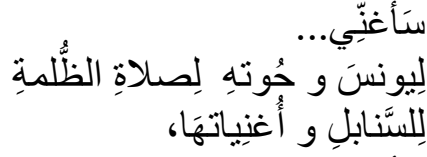

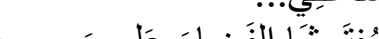

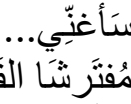

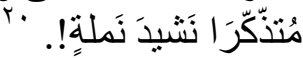


ولعلني لا أجانب الصواب إن قلت إن الاستعارة وحدها هي التي تستطيع أن تعكس هذه الحالة التي يمر بها الثاني الثاعر. في نهاية ألمطاف أود أن أثنير إلى أن شعر ما بعد الحداثة عاد بالأدب إلى إلى معناه

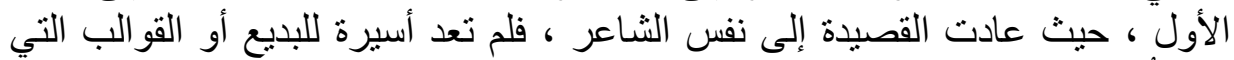

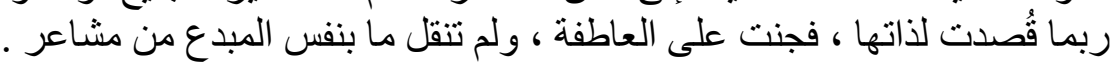

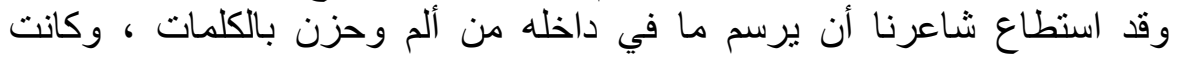

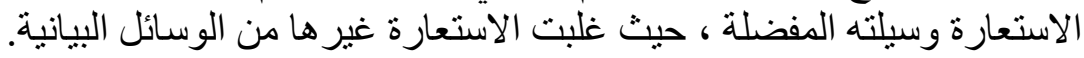

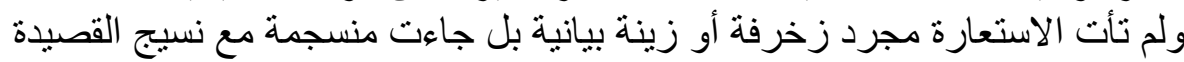

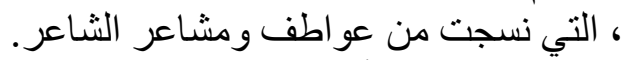
فئن خلالها قر أنا الماضي و عشنا الحاضر و واستشرفنا المستقبل ، فهي مفتاح الثاعر و إن جاءت غامضة أحيانا ؛فذلك لأن غموضها يعكس غموض رؤية الثاعر وحيرته فيما أز عم. و عدم استقر ار مشاعره بسبب أحز انه و آلامه. 


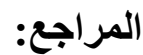

ا - روبرت هولب : نظرية التلقى ، ترجمة د.عز الدين إسماعيل ، المكتبة الأكاديميـة ،

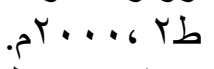

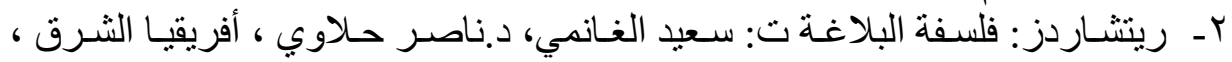

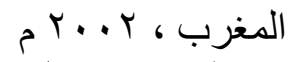

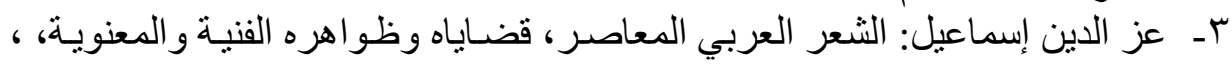

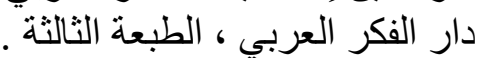

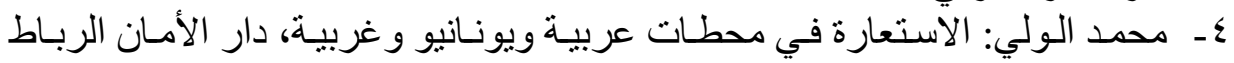

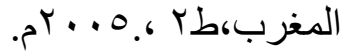

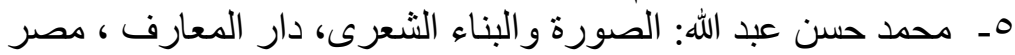

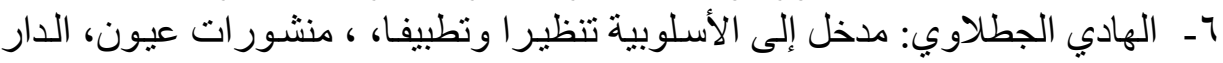

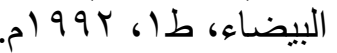

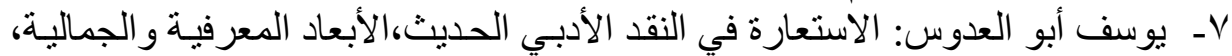

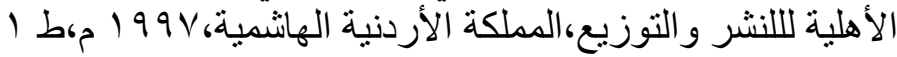

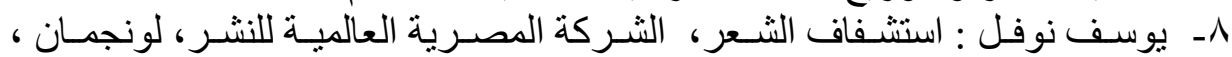

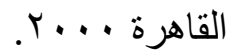

9- Eco, U : A Theory of Semiotics, Indiana University Press, 1976 10-Brown . G . Yule : Discourse Analysis . Cambridge. 1983 
